\title{
Quality of life and changes in the social dimension of hematopoietic stem cell transplants recipients
}

\author{
Qualidade de vida e alterações no domínio social de transplantados de células-tronco hematopoéticas
}

Calidad de vida y cambios en el dominio social de los receptores de trasplantes de células madre hematopoyéticas

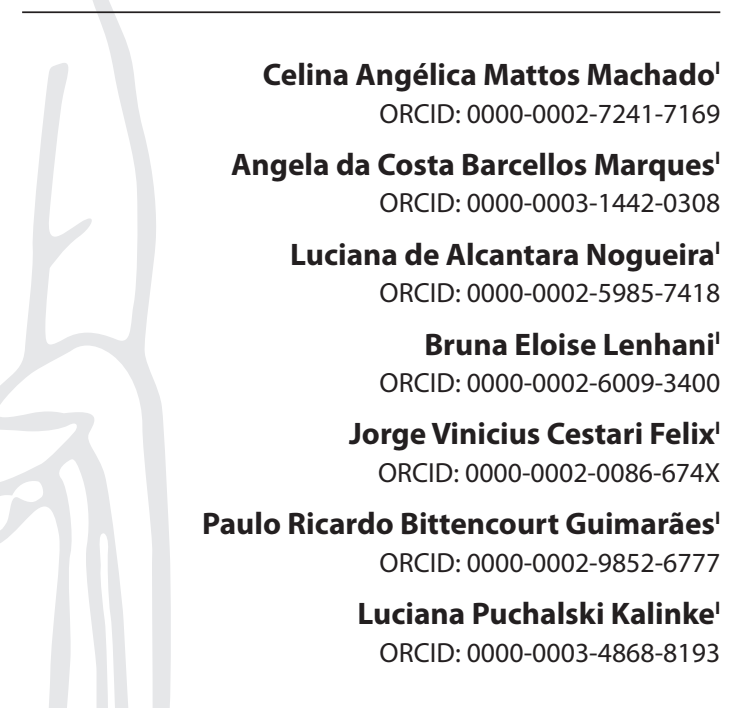

'Universidade Federal do Paraná. Curitiba, Paraná, Brazil.

How to cite this article:

Machado CAM, Marques ACB, Nogueira LA, Lenhani BE, Felix JVC, Guimarães PRB, et al. Quality of life and changes in the social dimension of hematopoietic stem cell transplants recipients. Rev Bras Enferm. 2021;74(1):e20200644. doi: http://dx.doi.org/10.1590/0034-7167-2020-0644

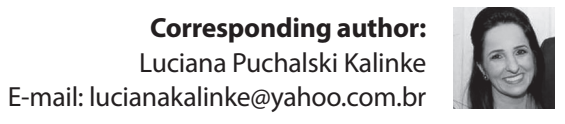

EDITOR IN CHIEF: Antonio José de Almeida Filho ASSOCIATE EDITOR: Fátima Helena Espírito Santo

Submission: 07-29-2020 Approval: 09-29-2020

\begin{abstract}
Objectives: to assess/correlate health-related quality of life with the social dimension of hematopoietic, autologous and allogeneic stem cell transplant patients in the three years post-transplant. Methods: longitudinal, observational study with 55 patients, in a reference hospital in Latin America, from September 2013 to February 2019, using the Quality of Life Questionnaire-Core and Functional Assessment Cancer Therapy Bone Marrow Transplantation. Results: A total of $71 \%$ underwent allogeneic transplantation. The social dimension had low averages since the baseline stage $(55,21)$ and low scores $(56)$ for quality of life in pancytopenia. There was a significant positive correlation between social dimension, quality of life in pancytopenia $(p<0.01)$ and follow-up after hospital discharge $(p<0.00)$. There is a significant difference $(p<0.00)$ throughout the stages, however, not in terms of the type of transplant ( $p>0.36 / 0.86$ ). Conclusions: patients with better assessments in the social dimension have a better quality of life. Interventions focusing on the multidimensionality of the quality of life construct are necessary.

Descriptors: Quality of Life; Hematopoietic Stem Cell Transplantation; Social Isolation; Oncology Nursing; Neoplasms.
\end{abstract}

\section{RESUMO}

Objetivos: avaliar/correlacionar a qualidade de vida relacionada à saúde com o domínio social de pacientes transplantados de células-tronco hematopoéticas, autólogo e alogênico, nos três anos pós-transplante. Métodos: estudo longitudinal, observacional, com 55 pacientes, num hospital referência da América Latina, de setembro de 2013 a fevereiro de 2019, com - Quality of Life Questionnarie-Core e Functional Assessment Cancer Therapy Bone Marrow Transplantation. Resultados: $71 \%$ realizaram transplante alogênico. O domínio social apresentou médias baixas desde a etapa basal $(55,21)$ e escores baixos $(56)$ para a qualidade de vida na pancitopenia. Houve correlação positiva significativa entre domínio social, qualidade de vida na pancitopenia $(p<0,01)$ e acompanhamento após alta hospitalar $(p<0,00)$. Observa-se diferença significativa $(p<0,00)$ ao longo das etapas, porém, não quanto à modalidade de transplante $(p>0,36 / 0,86)$. Conclusões: pacientes com melhor avaliação no domínio social apresentam melhor qualidade de vida. Intervenções com foco na multidimensionalidade do constructo qualidade de vida são necessárias.

Descritores: Qualidade de Vida; Transplante de Células-Tronco Hematopoéticas; Isolamento Social; Enfermagem Oncológica; Neoplasias.

\section{RESUMEN}

Objetivos: evaluar/correlacionar la calidad de vida relacionada a la salud con el ámbito social de pacientes trasplantados de células madre hematopoyéticas, autólogas y alogénicas, tres años post trasplante. Métodos: se trata de un estudio longitudinal, observacional, llevado a cabo en un hospital referencial de América Latina con 55 pacientes entre septiembre de 2013 y febrero de 2019, utilizando la Escala de Calidad de Vida-Núcleo y la Evaluación funcional de la terapia del cáncer: trasplante de médula ósea. Resultados: el $71 \%$ realizó un trasplante alogénico; el ámbito social presentó promedios bajos desde la etapa inicial $(55,21)$ y puntuaciones bajas (56) en cuanto a la calidad de vida en la pancitopenia. Se observó una correlación positiva significativa entre el ámbito social, la calidad de vida en la pancitopenia $(p<0,01)$ y el seguimiento después del alta hospitalaria $(p<0,00)$. Hubo una diferencia significativa $(p<0,00)$ a lo largo de los estadios, pero no en lo que respecta a la modalidad del trasplante $(p>0,36 / 0,86)$. Conclusiones: aquellos pacientes con mejor evaluación en el ámbito social presentan mejor calidad de vida. Es necesario realizar intervenciones que se centren en la multidimensionalidad de la construcción de la calidad de vida.

Descriptores: Calidad de Vida; Trasplante de Células Madre Hematopoyéticas; Aislamiento Social; Enfermería Oncológica; Neoplasias. 


\section{INTRODUCTION}

Hematological cancer, among which leukemias and lymphomas are included, has become common worldwide. According to the International Agency for Research on Cancer (IARC), the number of new cases of leukemia and lymphoma in 2018 was nearly 437 thousand and 589 thousand, respectively. For the year 2040, this estimate will increase to more than 656 thousand new cases for leukemia and 918 thousand for lymphoma ${ }^{(1)}$. In Brazil, according to the Instituto Nacional do Câncer José Alencar Gomes da Silva (INCA) (National Cancer Institute José Alencar Gomes da Silva), for the period 2020-2022, it is estimated that 10,810 and 14,670 new cases of leukemia and lymphoma will occur, respectively ${ }^{(2)}$.

Among the therapeutic options for hematological cancer patients is the Hematopoietic Stem Cell Transplantation (HSCT), which can be of the autologous type, when the cells come from the patient him/herself, or allogeneic, when they come from another individual, being a relative or not. The choice of the origin of the cells and their modality depend on the disease, the patient's clinical conditions and the availability of donors ${ }^{(3)}$.

The therapeutic process of HSCT includes stages and a long hospital stay, times when the patient remains restricted to the transplant sector, with or without the presence of a companion. The patient stays on work leave and away from professional relationships, family members and other coexistence, due to immune suppression and the high chances of catching infections ${ }^{(4)}$. This seclusion causes the patient to experience important social isolation, which triggers fear, anxiety, depression, besides feeling insecure about the future, causing feelings that negatively affect their health-related quality of life (HRQoL) ${ }^{(5)}$.

The concept of HRQoL comprises the individual's perception of the life condition in case of a disease, the consequences of treatment and how the disease affects his life condition. Thus, assessing it is to quantitatively measure changes in the individual's quality of life during the treatment. The instruments used are specific for this purpose and involve the dimensions that make up the quality of life construct, namely: physical, emotional, spiritual, functional and social ${ }^{(6)}$.

The social dimension in this study includes the social function, assessed by the Quality of Life Questionnaire - Core 30 (QLQ-C30), from the European Organization Research Treatment of Cancer (EORTC), and the social/family well-being, assessed by Functional Assessment of Cancer Therapy - Bone Marrow Transplant (FACTBMT), from the Functional Assessment of Chronic Illness Therapy (FACIT), and is related to friendships, the support received from family members regarding the emotional issue and acceptance of the disease, sexual desire, among other issues ${ }^{(7)}$. In HSCT, these demands may change due to the treatment dynamics, which requires social isolation related to the impairment of the immune system, symptoms, and various complications that it can cause.

\section{OBJECTIVES}

To evaluate and correlate health-related quality of life with the social dimension of hematopoietic, autologous, and allogeneic stem cell transplant patients in the three years post-transplant.

\section{METHODS}

\section{Ethical aspects}

This study was approved by the Research Ethics Committee of the Health Sciences Department of the Universidade Federal do Paraná. The informed consent form was signed by the participants. To guarantee their confidentiality, a numerical sequence $(1,2,3$, $4, . .$.$) was assigned to the participants' identity as the inclusion of$ the participants occurred.

\section{Study design, period, and setting}

This is an observational study that followed the recommendations of the Strengthening the Reporting of Observational Studies in Epidemiology $(\mathrm{STROBE})^{(8)}$, longitudinal and analytical initiative, carried out from September 2013 to February 2019, at the Bone Marrow Transplant Service (STMO) of a public hospital, reference in Latin America, located in southern Brazil.

\section{Sample, inclusion and exclusion criteria}

This was not a probabilistic sampling, however, it is based on the average number of patients who underwent HSCT in the years 2010 to 2012, with an increase of $50 \%$ because of possible losses due to the characteristics of the treatment. Authors ${ }^{(9)}$ emphasize the existence of high rates of morbidity and mortality related to HSCT.

The sample consisted of 55 participants who met the inclusion criteria: age equal to or greater than 18 years, with a hematological cancer diagnosis and undergoing HSCT. Participants who did not have the physical conditions to fill out the instruments were excluded. Five patients were discontinued due to loss of follow-up. Also, 28 patients died over the three years after HSCT (five in pancytopenia, one in pre-discharge, six in the post 100 days, two in the post 180 days, six in the post 360 days, five in the post two years and three after three years), resulting in 22 patients in the third year.

\section{Study protocol}

Data collection was carried out in eight stages: baseline or pre-HSCT; pancytopenia; pre-hospital discharge (after successful medullary grafting); after 100 days of HSCT; post 180 days; post 360 days; after two years; after three years. Sociodemographic and clinical data were obtained using a specific questionnaire, created by the researchers, applied at the baseline stage to characterize the participants and, after 180 days, in all stages to update information and identifying possible late adverse events. The QLQ-C30 questionnaires, version 3.0, and the FACT-BMT, version 4.0, translated and validated into Brazilian Portuguese, were applied in all stages ${ }^{(10-12)}$.

The QLQ-C30 is a generic questionnaire used to assess the HRQoL of patients diagnosed with cancer, composed of 30 questions, divided into the functional scale (physical, emotional, social function, cognitive performance and personal performance), symptom scale/ simple items and HRQoL. Rages are expressed from 0 to 100: the higher the score, the better the assessment of HRQoL; on the symptom scale, the higher the score, the higher 
the symptoms and the lower the HRQoL ${ }^{(13)}$. For this study, only data related to social function were used, which involve pertinent questions about how the physical condition or medical treatment interfere with family life and/or social activities.

The FACT-BMT is a specific questionnaire to assess HRQoL for patients who underwent HSCT, composed of 50 questions distributed in five dimensions (physical well-being, social/family well-being, functional well-being, emotional well-being, and additional concerns). For social/family well-being, Ranges are expressed from 0 to 28 , with higher scores indicating a better assessment ${ }^{(14)}$. FACT-BMT data related to social/family well-being covers issues such as having good friendships, receiving emotional support from family and friends, acceptance of the disease by the family, feeling close to the person who provides the most support and satisfaction with sex life.

Both instruments have Likert formatting. The QLQ-C30 has two questions with the semantic differential (SD) technique, which is characterized by the presentation of a concept and adjectives with extreme scores, associated with the seven-point assessment scale. Adjectives with higher values are classified as positive.

The use of the questionnaires was authorized upon registration of the project with EORTC and FACIT, which made them available directly to researchers via download.

\section{Analysis of results and statistics}

Sociodemographic and clinical data were analyzed using descriptive statistics, presented by absolute and relative frequency. The data were arranged in tables, presented in mean and standard deviation, and analyzed according to EORTC and FACIT scoring guidelines. The Statistica 7.0 software was used for correlations and SPSS 20 for the adjustment of longitudinal models.

To verify the relationship between HRQoL scores, the social function of QLQ-C30 and the social/family well-being of FACT-BMT, the Spearman correlation coefficient was obtained. To assess the progression over time and the associations between groups (autologous and allogeneic), stages and groups/stages, the Generalized Linear Mixed Model (GLMM) was applied, using the SPSS 20 Software.

The GLMM approach allowed us to consider all observations in the study period, including those patients who did not participate in the research until the end (five due to follow-up loss and 28 due to death, totaling to 55 the number of participants at the beginning of the study and 22 at the end). It was possible to evaluate the time (eight stages) and group (autologous versus allogeneic) factors, as well as a possible interaction effect between stages and group. The model was adjusted considering the patients as a random effect and AR1 covariance matrix. The best fit was defined by the AIC (Akaike Information Criterion). The assumption of residual normality was tested using the QQ plot graph and the analysis of multiple paired comparisons was performed using the Sidak test ${ }^{(15)}$.

\section{RESULTS}

As for the sociodemographic and clinical characterization, among the 55 patients included in the study, 16 (29\%) were patients in the autologous group, with a mean age of 45 years (min. range 19 years - max. 69 years), and 39 (71\%) of the allogeneic group, with a mean age of 31 years (min. range 18 years - max. 59 years). Moreover, 11 (68.75\%) autologous and 19 (48.72\%) allogeneic patients were married or in a domestic partnership. Regarding the diagnosis, 36 (92.32\%) of those who had allogeneic HSCT were diagnosed with some type of leukemia.

When assessing HRQoL, the social function of the QLQ C-30 questionnaire and the correlation between them, the results in Table 1 show that the participants had worse scores in the pancytopenia stage. Furthermore, there was a positive correlation between the variables, with significant results from the pancytopenia period, indicating that the better the social function, the better the HRQoL.

After 3 years of HSCT, patients in the total group assessed their HRQoL better than at the pre-HSCT baseline. This situation differs in the social function assessment, in which the averages of this dimension, since the baseline stage, showed impairment.

When assessing the HRQoL results of the QLQ C30 and the FACT-BMT social/family well-being, it was possible to observe in Table 2 that there was a positive correlation between HRQoL and social/family well-being, with significance from the post-HSCT 360 days until post-HSCT three years.

When analyzing HRQoL and social function (QLQ-C30), by a group of patients (autologous and allogeneic), it can be observed in Table 3 that there was a loss in these scores in the pancytopenia stage, with a better assessment in the following stages. When the correlation test between HRQoL and social function was carried out, it was possible to observe that the autologous HSCT group showed a positive correlation, with significance in the stages after 180 days up to 2 years after HSCT, while the allogeneic group showed significance at all times, except pre-discharge. It is suggested that the better the social function, the better the $\mathrm{HRQ}$ L in these stages, individually.

Table 1 - Correlation between Health-Related Quality of Life and social function of the Quality of Life Questionnaire - Core 30, obtained in the eight stages of hematopoietic stem cell transplantation ( $n=55)$, Curitiba, Paraná, Brazil, 2013-2019

\begin{tabular}{|c|c|c|c|c|c|c|c|c|}
\hline & $\begin{array}{c}\text { Pre-HSCT } \\
n=55 \\
\text { Mean SD }\end{array}$ & $\begin{array}{c}\begin{array}{c}\text { Pancytopenia } \\
\mathbf{n}=50\end{array} \\
\text { Mean SD }\end{array}$ & $\begin{array}{c}\begin{array}{c}\text { Pre-discharge } \\
n=49\end{array} \\
\text { Mean SD }\end{array}$ & $\begin{array}{c}\text { Post-HSCT } \\
100 \text { days } \\
n=41 \\
\text { Mean SD }\end{array}$ & $\begin{array}{c}\text { Post-HSCT } \\
180 \text { days } \\
n=38 \\
\text { Mean SD }\end{array}$ & $\begin{array}{c}\text { Post-HSCT } \\
360 \text { days } \\
n=32 \\
\text { Mean SD }\end{array}$ & $\begin{array}{c}\text { Post-HSCT } \\
2 \text { years } \\
n=25 \\
\text { Mean SD } \\
\end{array}$ & $\begin{array}{c}\text { Post-HSCT } \\
3 \text { years } \\
n=22 \\
\text { Mean SD }\end{array}$ \\
\hline HRQoL & $\begin{array}{l}76.82 \\
17.69\end{array}$ & $\begin{array}{l}56.67 \\
20.27\end{array}$ & $\begin{array}{l}69.05 \\
19.17\end{array}$ & $\begin{array}{l}74.39 \\
21.28\end{array}$ & $\begin{array}{l}76.97 \\
20.27\end{array}$ & $\begin{array}{l}71.35 \\
20.62\end{array}$ & $\begin{array}{l}73.67 \\
21.07\end{array}$ & $\begin{array}{l}81.44 \\
15.20\end{array}$ \\
\hline SF & $\begin{array}{l}55.15 \\
31.89\end{array}$ & $\begin{array}{l}37.67 \\
31.19\end{array}$ & $\begin{array}{c}33.28 \\
0.26\end{array}$ & $\begin{array}{c}38.39 \\
0.44\end{array}$ & $\begin{array}{c}33.02 \\
0.63\end{array}$ & $\begin{array}{c}28.27 \\
0.58\end{array}$ & $\begin{array}{c}29.94 \\
0.88\end{array}$ & $\begin{array}{c}33.94 \\
0.70\end{array}$ \\
\hline Spearman & 0.23 & 0.34 & 0.26 & 0.44 & 0.63 & 0.58 & 0.88 & 0.70 \\
\hline$p$ value & 0.09 & $0.01^{*}$ & 0.06 & $0.00 *$ & $0.00^{*}$ & $0.00 *$ & $0.00^{*}$ & $0.00^{*}$ \\
\hline
\end{tabular}

Note: ${ }^{*} p<0.05 ;$ SF - Social Function; SD - Standard Deviation, HRQoL - Health-Related Quality of Life; HSCT - Hematopoietic Stem Cell Transplantation 
Table 2 - Correlation between Health-Related Quality of Life and the social function of the Quality of Life Questionnaire - Core 30 and the social/family well-being of the Functional Assessment of Cancer Therapy - Bone Marrow Transplant, obtained in the eight stages of cell transplantation- hematopoietic stem ( $\mathrm{n}=55)$, Curitiba, Paraná, Brazil, 2013-2019

\begin{tabular}{|c|c|c|c|c|c|c|c|c|}
\hline Scores & $\begin{array}{c}\text { Pre-HSCT } \\
n=55 \\
\text { Mean SD }\end{array}$ & $\begin{array}{c}\begin{array}{c}\text { Pancytopenia } \\
n=50\end{array} \\
\text { Mean SD }\end{array}$ & $\begin{array}{c}\begin{array}{c}\text { Pre-discharge } \\
n=49\end{array} \\
\text { Mean SD }\end{array}$ & $\begin{array}{c}\text { Post-HSCT } \\
100 \text { days } \\
n=41 \\
\text { Mean SD }\end{array}$ & $\begin{array}{c}\text { Post-HSCT } \\
180 \text { days } \\
n=38 \\
\text { Mean SD }\end{array}$ & $\begin{array}{c}\text { Post-HSCT } \\
360 \text { days } \\
n=32 \\
\text { Mean SD }\end{array}$ & $\begin{array}{c}\text { Post-HSCT } \\
\begin{array}{c}2 \text { years } \\
n=25\end{array} \\
\text { Mean SD }\end{array}$ & $\begin{array}{c}\text { Post-HSCT } \\
\begin{array}{c}3 \text { years } \\
n=22\end{array} \\
\text { Mean SD }\end{array}$ \\
\hline HRQoL (QLQ C-30) & $\begin{array}{l}76.82 \\
17.69\end{array}$ & $\begin{array}{l}56.67 \\
20.27\end{array}$ & $\begin{array}{l}69.05 \\
19.17\end{array}$ & $\begin{array}{l}74.39 \\
21.28\end{array}$ & $\begin{array}{l}76.97 \\
20.27\end{array}$ & $\begin{array}{l}71.35 \\
20.62\end{array}$ & $\begin{array}{l}73.67 \\
21.07\end{array}$ & $\begin{array}{l}81.44 \\
15.20\end{array}$ \\
\hline SFWB & $\begin{array}{c}21.07 \\
5.24\end{array}$ & $\begin{array}{c}18.15 \\
5.17\end{array}$ & $\begin{array}{c}17.36 \\
5.38\end{array}$ & $\begin{array}{c}20.09 \\
6.14\end{array}$ & $\begin{array}{c}21.12 \\
5.78\end{array}$ & $\begin{array}{c}20.06 \\
5.66\end{array}$ & $\begin{array}{c}21.62 \\
3.63\end{array}$ & $\begin{array}{c}20.45 \\
6.02\end{array}$ \\
\hline Spearman & -0.00 & -0.19 & -0.02 & 0.15 & 0.29 & 0.46 & 0.75 & 0.53 \\
\hline$p$ value & 0.95 & 0.16 & 0.88 & 0.33 & 0.07 & $0.00^{*}$ & $0.00^{*}$ & $0.0^{*}$ \\
\hline
\end{tabular}

Note: * $p<0.05 ;$ SFWB - Social and Family Well-Being; SD - Standard Deviation, HRQoL - Health-Related Quality of Life, HSCT - Hematopoietic Stem Cell Transplant.

Table 3 - Correlation of Health-Related Quality of Life scores and social function of the Quality of Life Questionnaire - Core and the social/family well-being of the Functional Assessment of Cancer Therapy - Bone Marrow Transplant, obtained in the eight stages of cell transplantation -hematopoietic stem in autologous ( $n=16$ ) and allogeneic ( $n=39$ ) modalities, Curitiba, Paraná, Brazil, 2013-2019

\begin{tabular}{|c|c|c|c|c|c|c|c|c|c|c|c|c|c|c|c|c|}
\hline & \multicolumn{2}{|c|}{$\begin{array}{l}\text { Pre-HSCT } \\
\text { Mean SD }\end{array}$} & \multicolumn{2}{|c|}{$\begin{array}{c}\text { Pancytopenia } \\
\text { Mean SD }\end{array}$} & \multicolumn{2}{|c|}{$\begin{array}{c}\text { Pre-discharge } \\
\text { Mean SD }\end{array}$} & \multicolumn{2}{|c|}{$\begin{array}{c}\text { Post-HSCT } \\
100 \text { days } \\
\text { Mean SD }\end{array}$} & \multicolumn{2}{|c|}{$\begin{array}{l}\text { Post-HSCT } \\
180 \text { days } \\
\text { Mean SD }\end{array}$} & \multicolumn{2}{|c|}{$\begin{array}{c}\text { Post-HSCT } \\
360 \text { days } \\
\text { Mean SD }\end{array}$} & \multicolumn{2}{|c|}{$\begin{array}{l}\text { Post-HSCT } \\
2 \text { years } \\
\text { Mean SD }\end{array}$} & \multicolumn{2}{|c|}{$\begin{array}{l}\text { Post-HSCT } \\
3 \text { years } \\
\text { Mean SD }\end{array}$} \\
\hline & $\underset{n=16}{\text { Aut }}$ & $\underset{n=39}{\text { All }}$ & $\underset{n=16}{\text { Aut }}$ & $\underset{n=34}{\text { All }}$ & $\underset{n=16}{\text { Aut }}$ & $\underset{n=33}{\text { All }}$ & $\begin{array}{l}\text { Aut } \\
n=13\end{array}$ & $\underset{n=28}{\text { All }}$ & $\underset{n=12}{\text { Aut }}$ & $\underset{n=26}{\text { All }}$ & $\begin{array}{c}\text { Aut } \\
n=11\end{array}$ & $\begin{array}{c}\text { All } \\
n=21\end{array}$ & $\begin{array}{l}\text { Aut } \\
n=7\end{array}$ & $\underset{n=18}{\text { All }}$ & $\begin{array}{l}\text { Aut } \\
n=4\end{array}$ & $\underset{n=18}{\text { All }}$ \\
\hline HRQoL & $\begin{array}{l}70.8 \\
16.3\end{array}$ & $\begin{array}{l}79.2 \\
17.8\end{array}$ & $\begin{array}{l}59.3 \\
19.2\end{array}$ & $\begin{array}{l}55.3 \\
20.9\end{array}$ & $\begin{array}{l}73.9 \\
15.1\end{array}$ & $\begin{array}{l}66.7 \\
20.6\end{array}$ & $\begin{array}{l}80.7 \\
13.3\end{array}$ & $\begin{array}{l}71.4 \\
23.7\end{array}$ & $\begin{array}{l}75.6 \\
21.4\end{array}$ & $\begin{array}{l}77.5 \\
20.1\end{array}$ & $\begin{array}{l}72.7 \\
16.7\end{array}$ & $\begin{array}{l}70.6 \\
22.7\end{array}$ & $\begin{array}{l}63.1 \\
28.8\end{array}$ & $\begin{array}{l}77.7 \\
16.4\end{array}$ & $\begin{array}{l}75.0 \\
21.5\end{array}$ & $\begin{array}{l}82.8 \\
13.8\end{array}$ \\
\hline FS & $\begin{array}{l}62.5 \\
33.6\end{array}$ & $\begin{array}{l}52.1 \\
31.1\end{array}$ & $\begin{array}{l}46.8 \\
29.3\end{array}$ & $\begin{array}{r}33.3 \\
31.5\end{array}$ & $\begin{array}{c}46.8 \\
28\end{array}$ & $\begin{array}{l}35.8 \\
35.3\end{array}$ & $\begin{array}{l}71.7 \\
32.1\end{array}$ & $\begin{array}{c}52.9 \\
40\end{array}$ & $\begin{array}{l}86.1 \\
18.5\end{array}$ & $\begin{array}{l}67.9 \\
36.7\end{array}$ & $\begin{array}{l}81.8 \\
26.3\end{array}$ & $\begin{array}{l}75.4 \\
29.6\end{array}$ & $\begin{array}{l}59.5 \\
40.6\end{array}$ & $\begin{array}{c}85.1 \\
22\end{array}$ & $\begin{array}{l}66.6 \\
40.8\end{array}$ & $\begin{array}{l}79.6 \\
33.1\end{array}$ \\
\hline $\begin{array}{l}\text { Spearman HRQoL } \\
\text { and SF }\end{array}$ & 0.05 & 0.37 & 0.27 & 0.34 & 0.15 & 0.28 & 0.37 & 0.47 & 0.79 & 0.59 & 0.78 & 0.50 & 0.79 & 0.83 & 0.73 & 0.64 \\
\hline$p$ value & 0.82 & $0.02^{*}$ & 030 & $0.04^{*}$ & 0.57 & 0.10 & 0.20 & $0.01^{*}$ & $0.00^{*}$ & $0.00^{*}$ & $0.00^{*}$ & $0.02^{*}$ & $0.03^{*}$ & $0.00^{*}$ & 0.26 & $0.00^{*}$ \\
\hline SFWB & $\begin{array}{c}20.8 \\
6.9\end{array}$ & $\begin{array}{c}21.1 \\
4.4\end{array}$ & $\begin{array}{l}17.0 \\
6.5\end{array}$ & $\begin{array}{c}18.6 \\
4.3\end{array}$ & $\begin{array}{l}16.7 \\
6.7\end{array}$ & $\begin{array}{c}17.6 \\
4.6\end{array}$ & $\begin{array}{c}19.9 \\
7.9\end{array}$ & $\begin{array}{c}20.1 \\
5.2\end{array}$ & $\begin{array}{c}20.8 \\
5.7\end{array}$ & $\begin{array}{c}21.2 \\
5.9\end{array}$ & $\begin{array}{l}20.7 \\
7.9\end{array}$ & $\begin{array}{c}19.7 \\
4.4\end{array}$ & $\begin{array}{c}21.5 \\
4.8\end{array}$ & $\begin{array}{c}21.6 \\
3.1\end{array}$ & $\begin{array}{l}16.8 \\
11.3\end{array}$ & $\begin{array}{c}21.3 \\
4.1\end{array}$ \\
\hline $\begin{array}{l}\text { Spearman } \\
\text { HRQoL and SFWB }\end{array}$ & -0.46 & 0.26 & -0.38 & -0.06 & -0.27 & 0.09 & 0.45 & 0.00 & 0.59 & 0.16 & 0.78 & 0.29 & 0.54 & 0.62 & 1 & 0.33 \\
\hline$p$ value & 0.06 & 0.10 & 0.14 & 0.72 & 0.30 & 0.59 & 0.11 & 0.96 & $0.04^{*}$ & 0.42 & $0.00^{*}$ & 0.19 & 0.20 & $0.00^{*}$ & - & 0.01 \\
\hline
\end{tabular}

Note: Numerical data equal to zero not resulting from rounding; * $p<0.05$; Aut - Autologous; All - Allogeneic; SF - Social Function; SFWB - Social and Family Well-Being; SD - Standard Feviation, HRQoL - Health-Related Quality of Life; HSCT - Hematopoietic Stem Cell Transplantation.

Table 4 - Analysis of the Mixed Generalized Linear Model of Health-Related Quality of Life, social function and social/family well-being between groups (Autologous versus Allogeneic), stages (8 stages) and group/stage interaction, Curitiba, Paraná, Brazil, 2013-2019, $(n=55)$

\begin{tabular}{|c|c|c|c|c|c|c|}
\hline \multirow{2}{*}{ Factors } & \multicolumn{2}{|c|}{ HRQoL } & \multicolumn{2}{|c|}{ Social function } & \multicolumn{2}{|c|}{ Social/family well-being } \\
\hline & $\mathbf{F}$ & $p$ & $\mathbf{F}$ & $p$ & $\mathbf{F}$ & $P$ \\
\hline Intercept & 1362.54 & 0.00 & 262.49 & $0.00^{*}$ & 890.64 & 0.00 \\
\hline Group & 0.25 & 0.61 & 0.84 & 0.36 & 0.03 & 0.86 \\
\hline Stage & 6.18 & $0.00 *$ & 7.97 & $0.00^{*}$ & 6.83 & $0.00^{*}$ \\
\hline Groups/Stage & 1.65 & 0.12 & 1.34 & 0.23 & 0.58 & 0.76 \\
\hline
\end{tabular}

Note: ${ }^{*} p<0.05 ;$ HRQoL - Health-Related Quality of Life; $F-$ Snedecor Statistics.

When correlating HRQoL and social/family well-being assessed by FACT-BMT, it is observed that patients undergoing autologous HSCT have a significant positive correlation in the 180-day post-HSCT and 360-day post-HSCT stage. In allogeneic HSCT patients, there was a positive correlation, with significance in the moments 2 and 3 years post-HSCT, indicating that, in these stages, the higher the score of social/family well-being the better the HRQoL, which is in agreement correlation between HRQoL and social function of the QLQ-C30.

In the analysis of the overtime evolution of HRQoL scores, social function, and social/family well-being, the GLMM was used and adjusted considering the patients as a random effect. The best fit was defined by the AIC criterion (AIC: HRQoL=2576.07; social function $=2829.60$; social/family well-being $=1727.20$ ). . The assumption of normality of the residues was verified through the QQ plot graph, with confirmatory results.

Table 4 presents the results of the final GLMM analysis for the group, stage, and group/stage interaction factors. There is a significant difference in $\mathrm{HRQ}$ L, social function and social/family well-being only between the stages. There is no difference between groups, much less in group/stage interaction. 

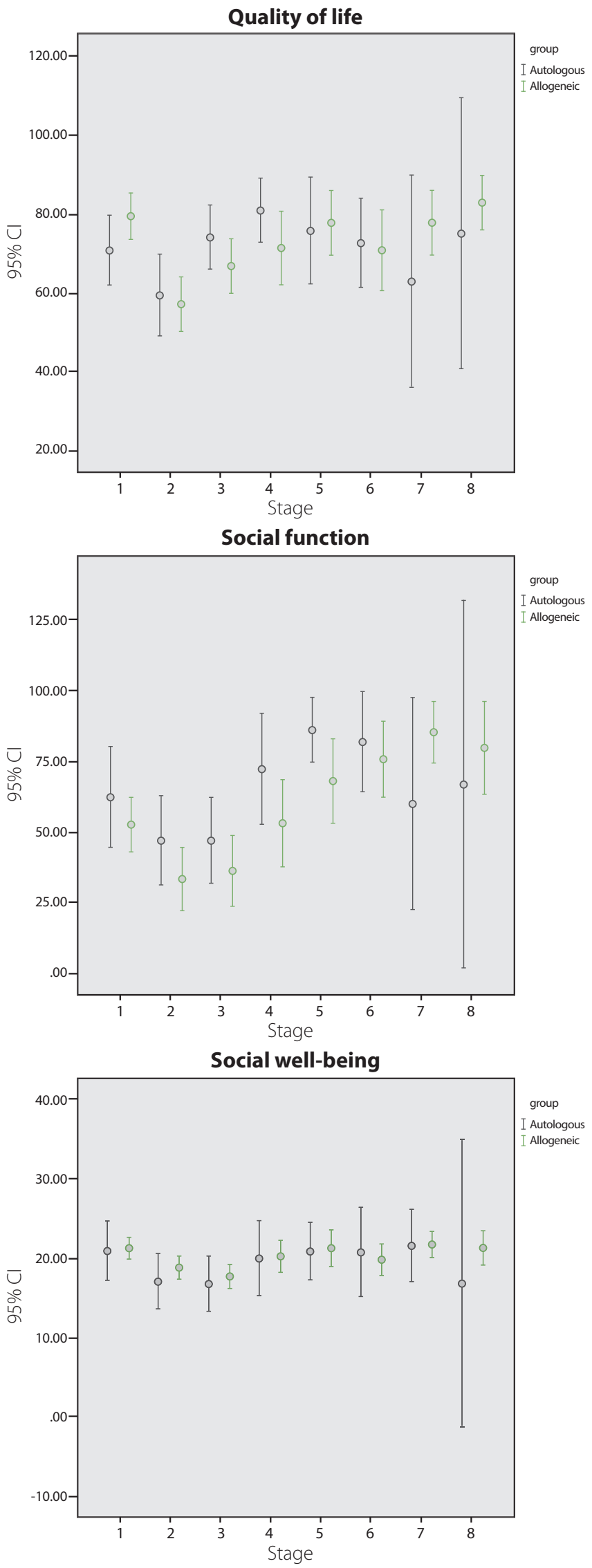

Figure 1 - Progression of Health-Related Quality of Life, social function and social/family well-being scores throughout the stages ( $n=55)$, Curitiba, Paraná, Brazil, 2020
The multiple paired comparisons performed using the Sidak test point that the HRQoL, social function and social/family wellbeing indexes show a significant decrease in the pancytopenia stage (step 2), but increase again in the pre-discharge stage (step three), 100 days (step four) and 180 days (step five).

It can be observed, in Figure 1, that there is no difference in the behavior of the groups (autologous versus allogeneic) throughout the stages, both in the HRQoL index and in the social function and social/family well-being.

\section{DISCUSSION}

The cancer diagnosis is a stressful factor for the patient and his/ her family. Added to this is the fact that the possible therapies to be performed, including $\mathrm{HSCT}$, offer the hope of cure and survival, but have side effects and numerous risks. The feelings are intense for those involved, because in the first stages of treatment they are destabilized and weakened, due to the burden of concerns that afflicts them.

Social/family well-being and/or social function may be compromised mainly during the hospital stay. The isolation process, the discontinuation of some routine activities, financial difficulties and the return to the labor market, especially for adults and the elderly, who often have family responsibilities, cause conflict during the therapeutic journey. In this research, the average age of patients who underwent allogeneic transplantation was 31 years old, supporting a research carried out in Philadelphia ${ }^{(16)}$ whose mean age was 37 years old, and diverging from the review ${ }^{(17)} \mathrm{car}^{-}$ ried out in Japan, in which the age varied from 32 and 65 years and the average was 52 years. It is noteworthy that the average age found in the aforementioned studies is that of individuals who are in a productive phase of life, with professional engagement and family leadership, which can be an additional cause for concern, bringing out the feelings of anxiety and anguish.

A survey conducted in the United States highlighted that patients over 60 years old who had autologous HSCT were more likely to become hired than those aged from 18 to 39 years old ${ }^{(18)}$. Since this is an age group in which many begin the process of professional development, the leave from the professional activity may cause gaps to compete for a new job or win a promotion.

Marital status is also an important factor that can compromise social function and/or social/family well-being. In this research, there was a predominance of married or in a domestic partnership among patients undergoing HSCT. Having a partner is support for coping with the therapy, conveying safety and independence in performing the necessary care ${ }^{(19)}$. $\mathrm{HSCT}$ is a long process, which changes the family routine, often not allowing the continuous presence of a companion, especially during the hospitalization. This scenario can cause loneliness and discontent concerning their role in the family and society, and such feelings are intensified in the presence of children in the family.

Elements such as age and sex may be related to the increase or decrease in social/family well-being, after all, for young women and young children, the experience of being isolated and uncertainty about the future can be more traumatic than for older people or those without children. However, individual experiences this process in a very particular way, with the need for social and family 
support at any time. It is observed that HSCT changes the HRQoL of patients with hematological cancer during hospitalization, with impairment in several functions, including social function and social/family well-being ${ }^{(5)}$.

When the results of the QLQ-C30 questionnaire are observed, in which there is a significant positive correlation in both groups, this data suggests that the better the social/family well-being, the better the HRQoL assessment, that is, those who assessed their HRQoL as good, were not suffering so much the problems involving the social dimension, such as closeness to family and friends, support received etc. This may suggest that patients were feeling welcomed and well advised by their partner and family, and that contacts with friends (through social networks and technologies) could be kept. Furthermore, it can be said that there was a better acceptance of the disease by the family and that the treatment did not interfere in the family and social condition, issues that make up the concept of social/family function of the QLQ-C30 and FACT-BMT social/family well-being.

Pancytopenia and pre-discharge were the periods in which there was a greater impairment related to health quality of life and social function and social/family well-being. This result reveals that the fragility of the moment, caused by low immunity, and the fear of returning to routine influence the patient's assessment.

The involvement of the partner, friends and family is crucial for the patient to talk, interact and feel included in their daily lives, minimizing fear and depressive feelings about the disease and treatment. In this sense, technology can and should be used to support this involvement, to keep the patient close to those who, due to isolation, cannot attend the hospital for face-to-face visits. The use of a cell phone with internet access or other instruments can be an example to provide, besides image contact with loved ones, access to movies, music and social networks, reducing the distance between the patient and his/her life before the disease ${ }^{(20)}$.

Emphasizing this issue, the study ${ }^{(21)}$ that aimed to assess the relationship between $\mathrm{HRQ}$ L L and social support, using the instruments of perceived social support and HSCT FACT-BMT functional assessment, showed that social support showed a downward trend accentuated $(F=17.09, p<0.001)$ and $H R Q o L$ decreased in the first month, 103.61 (SD 19.14), constantly increasing overtime to 108.10 (SD 19.58) in three months and 110.02 (SD 18.00) in six months after HSCT.

HSCT is marked by expectations of a successful procedure, in which optimism and hope are very important. In the research ${ }^{(22)}$ carried out with adult patients for allogeneic transplantation during hospitalization and approximately 100 days after the procedure, the results showed positive psychological constructs, especially gratitude, determination and optimism. According to the study mentioned, in the beginning, the participants reported thankfulness for their donors and, afterward, hope for a cure was prevalent. These feelings can favor good HRQoL scores.

The improvement in the social function and social/family well-being scores, after the end of the hospitalization, is an expected result, since, during hospitalization, the patient remains isolated from family and friends, being only with the team and the companion. Therefore, after discharge, social life tends to be recovered ${ }^{(23)}$. However, the feeling of social isolation can be prolonged, especially when the patient comes from another area, because even after hospital discharge he/she needs to be followed up daily in the clinic, away from home, routine, and work activities.

According to a study carried out in the south of Brazil(20) on the moment of hospital discharge, the caregiver, when is a spouse, is affected by the routine imposed by post-HSCT care. The patient needs monitoring when going out and for many activities of daily living, which directly impacts on social life and professional performance, especially for young adults. In this sense, emotional support to the caregiver is necessary, because their life changes as a result of the care that the health condition of the partner/ family requires, a moment that becomes a burden that causes disharmony and unhappiness, which can compromise other areas of quality of life, such as the emotional dimension.

Interventions that improve HRQoL and in the social function and social/family well-being dimension should be offered to reduce the treatment impact and its side effects. A low-cost alternative to reduce the feeling of social confinement was used in a randomized clinical trial ${ }^{(24)}$ conducted at a University Hospital in southern Brazil using music therapy. The study observed that the intervention connected the patient to his/her socio-cultural acoustic environment and reestablished emotional balance, providing relaxation and, consequently, reducing the feeling of confinement.

The study ${ }^{(25)}$ that used, among other instruments, the QLQ-C30, to assess the effect of prana meditation on HRQoL, mental health and melatonin concentrations in cancer survivors, observed that after practicing for eight weeks the prana meditation, there was a significant improvement in the quality of life scores that included social function $(p=0.004)$.

The use of complementary and integrative practices (CIPs), such as music therapy, aromatherapy and meditation, can provide peace and comfort, making the environment more familiar and welcoming to the patient. A study ${ }^{(26)}$ that aimed to analyze the prevalence of CIPs in patients undergoing antineoplastic chemotherapy concluded that patients report benefits from its use, and it is important that nurses know the use prevalence and have the knowledge to suggest them, when necessary . Also, spirituality is equally relevant, considering that believing in something greater, transcendent, makes the patient more positive and strengthened for the treatment battles. According to a study ${ }^{(27)}$, faithful people feel stronger and better prepared to face difficulties and continue to fight for survival.

In this study, we could observe that HRQoL, even with reduced social function, remained between regular and good. A retrospective study ${ }^{(28)}$ conducted in Australia with patients undergoing allogeneic HSCT and survivors for more than 2 years found that $40 \%$ of patients reported HRQoL at levels comparable to the country's general population.

Another study ${ }^{(29)}$ carried out in Australia with HSCT survivors presented reports that patients were still struggling to have a good HRQoL, as they were unable to enjoy life as they did before treatment, and that work opportunities decreased, the social domain was restricted, besides to having complications in intimate relationships due to sexual functioning and fertility. This research shows that patients undergoing HSCT can have their HRQoL changed not only during treatment, but also carry consequences that can affect 
their HRQoL throughout their lives, due to the fear of recurrence and worsening as a result of the procedure.

In this research, it was observed that the HRQoL and the social dimension underwent significant changes between the stages. There was no difference between the groups (autologous versus allogeneic) or in the group/stage interaction. Research is expected to be sensitive to changes for both HSCT, autologous and allogeneic ${ }^{(30)}$. A study ${ }^{(31)}$ carried out in Spain corroborates the data presented here, when it concludes that the modality of the transplant (autologous versus allogeneic) does not influence HRQoL at any time evaluated, as well as another study ${ }^{(32)}$ in which the decline in HRQoL, fatigue and psychological symptoms did not differ by type of transplant.

\section{Study limitations}

The limitations of this study are centered on the small sample size, with the inability to generalize the findings.

\section{Contributions to the field of nursing and health}

This article contributes to the reflection for health professionals, especially nurses, that it is not only the physical dimension that changes in the HSCT treatment. Thus, it is necessary to have a comprehensive view, during all phases of HSCT, of the dimensions that permeate $\mathrm{HRQ}$ L, aiming to contribute to its balance.

\section{CONCLUSIONS}

In this study, it was possible to observe a positive correlation with the impact between the dimension of social function/social well-being/family and HRQoL in several stages of the HSCT process. Patients with better scores in the social dimension have better HRQoL. The HRQoL and the social dimension do not differ significantly by HSCT modality. These findings can serve as subsidies for conducting systematic assessments in the pre, intra and post-HSCT, to identify and help control the severity of physical symptoms, as well as improving the ability to cope with the disease and the social aspects that interfere in $\mathrm{HRQOL}$ during all phases involving the HSCT process.

\section{FUNDING}

CAPES - Brazil n88881.311846/2018-01. Araucária Foundation $15 / 2017$.

\section{REFERENCES}

1. World Health Organization. Early cancer diagnosis saves lives, cuts treatment costs. 3 February 2017. Geneva: WHO, 2017. [ cited 2019 jun 27] Available from: https://www.who.int/en/news-room/detail/03-02-2017-early-cancer-diagnosis-saves-lives-cuts-treatment-costs

2. Instituto Nacional de Câncer José Alencar Gomes da Silva. Estimativa 2020: incidência de câncer no Brasil / Instituto Nacional de Câncer José Alencar Gomes da Silva. - Rio de Janeiro: INCA, 2019. Available from: https://www.inca.gov.br/sites/ufu.sti.inca.local/files//media/ document//estimativa-2020-incidencia-de-cancer-no-brasil.pdf

3. Aljurf M, Weisdorf D, Alfraih F, Szer J, Müller C, Confer D, et al. “Worldwide Network for Blood \& Marrow Transplantation (WBMT) special article, challenges facing emerging alternate donor registries". Bone Marrow Transplant. [Internet]. 2019 [cited 2019 Feb 18];54:1179-1188. Available from: https://www.ncbi.nlm.nih.gov/pmc/articles/PMC6760540/pdf/41409_2019_Article_476.pdf

4. Young LK, Mansfield B, Mandoza J. Nursing Care of Adult Hematopoietic Stem Cell Transplant Patients and Families in the Intensive Care Unit An Evidence-based Review. Crit. care nurs. clin. North Am. [Internet]. 2017 [ cited 2020 mai 30]; 29(3):341-52. doi:10.1016/j. cnc.2017.04.009.

5. Rocha V, Proença SFFS, Marques ACB, Pontes L, Mantovani MF, Kalinke LP. Social impairment of patients undergoing hematopoietic stem cell transplant. Rev. bras. enferm. [Internet] 2016;69(3):454-60. Available from: https://www.scielo.br/pdf/reben/v69n3/0034-7167reben-69-03-0484.pdf.

6. World Health Organization (WHO). WHOQOL Measuring quality of life. Geneva, 1997 [ cited 2019 nov 14]. Available from: https://www.who. int/mental_health/media/68.pdf

7. Bush NE, Haberman M, Donaldson G, Keith M.Sullivan KM. Quality of life of 125 adults surviving 6-18 years after bone marrow transplantation. Soc. sci. med. [Internet] 1995 [cited 2019 jun 24]; 40:479-490. doi: 10.1016/0277-9536(94)00153-K.

8. Malta M, Cardoso LO, Bastos FI, Magnanini MMF, Silva CMFP. STROBE initiative: guidelines on reporting observational studies. Rev. saúde pública [Internet] 2010 [cited 2020 May 12]; 44(3): 559-565. Available from: https://www.scielo.br/pdf/rsp/v44n3/en_21.pdf

9. Pitombeira, BS, Paz A, Pezzi A, Amorin B, Valim V, Laureano A, et al. Validation of the EBMT Risk Score for South Brazilian Patients Submitted to Allogeneic Hematopoietic Stem Cell Transplantation. Bone Marrow Res. [Internet] 2013 [cited 2020 May 12]; 2013:565824. Available from: https://www.ncbi.nlm.nih.gov/pmc/articles/PMC3876681/pdf/BMR2013-565824.pdf

10. Franceschini J, Jardim, JR, Fernandes ALG, Jamnik S, Santoro IL. Reproducibility of the Brazilian Portuguese version of the European Organization for Research and Treatment of Cancer Core Quality of Life Questionnaire used in conjunction with its lung cancer-specific module. J. bras. pneumol. [Internet]. 2010 [cited 2020 Jun 27];36(5):595-602. Available from: https://www.scielo.br/pdf/jbpneu/v36n5/ en_v36n5a11.pdf.

11. Mastropietro AP,Oliveira ÉA, Santos MA, Voltarelli JC Functional Assessment of Cancer Therapy Bone Marrow Transplantation: Portuguese translation and validation. Rev. saúde pública [Internet] 2007 [cited 2020 Jun 27]; 41(2):1-8. Available from: https://www.scielo.br/pdf/rsp/ v41n2/en_14-5993.pdf. 
12. Paiva CE, Carneseca EC, Barroso EM, Camargo MG, Alfano ACC, Rugno FC, et al. Further evaluation of the EORTC QLQ-C30 psychometric properties in a large Brazilian cancer patient cohort as a function of their educational status. Support. care cancer [Internet] 2014 [cited 2020 Jun 27]; 22(8): 2151-2160. doi:10.1007/s00520-014-2206-3.

13. Fayers PM, Aaronson NK, Bjordal K, Groenvold M, Curan D, Bottoomley A. Onbehalf of the EORTC Qualityof Life Group: The EORTC QLQ C30 Scoring Manual. 3rd ed. Brussels (Be): European Organization for Research and Treatment of Cancer. [Internet] 2001 [cited 202027 May 12 ]. Available from: https://www.eortc.org/app/uploads/sites/2/2018/02/SCmanual.pdf

14. Functional Assessment of Chronic Illness Therapy (FACIT). FACT-BMT Scoring Guidelines (Version 4.0) [Internet]. Elmhurst: FACIT; 2003 [cited 2020 Jun 10]. Available from: http://www.facit.org/.

15. Stroup WW. Generalized Linear Mixed Models: Modern Concepts, Methods and Applications. 2012.555 p.

16. Wang J, Jiang Q, Xu L, Zhang XH, Chen H, Qin YZ et al. Allogeneic Stem Cell Transplantation versus Tyrosine Kinase Inhibitors Combined with Chemotherapy in Patients with Philadelphia Chromosome-Positive Acute Lymphoblastic Leukemia. Biol blood marrow transplant [Internet] 2018 [ cited 2019 nov 14]; 24(4):741-750. Available from: https://www.bbmt.org/action/showPdf?pii $=$ S1083-8791\%2817\%2931681-6.

17. Tokunaga M, Uto H, Takeuchi S, Nakano N, Kubota A, Tokunaga M, et al. Newly identified poor prognostic factors for adult T-cell leukemialymphoma treated with allogeneic hematopoietic stem cell transplantation. Leuk. lymphoma. [Internet] 2017 [ cited 2019 nov 14];58(1),3744. doi: 10.1080/10428194.2016.1187270.

18. Stepanikova I, Powroznik K, Cook KS, Tierney DK, Laport G. Long-term implications of cancer for work and financial wellbeing: Evidence from autologous hematopoietic cell transplantation (HCT) survivors. Maturitas [Internet] 2017 [cited Jun 27];105, 119-125. doi:10.1016/j. maturitas.2017.07.002.

19. Rocha V, Kalinke LP, Felix JVC, Mantovani MF, Maftum MA, Guimarães PRB. Qualidade de vida de pacientes internados submetidos ao transplante de células tronco hematopoiéticas. Rev. eletrônica. enferm. [Internet]. 2015 [cited May 12];17(4), 1-9. Available from: https:// www.revistas.ufg.br/fen/article/view/36037/20681.

20. Schnepper RA, Kalinke LP, Sarquis LMM, Mantovani MFM, Proença SFFS. Quality of life of the main caretakers of posthematopoietic stemcell transplant patients. Texto \& contexto enferm. [Internet] 2018 [ cited 2019 nov 14];27(3):e2850016. Available from: http://www.revenf. bvs.br/pdf/tce/v27n3/en_0104-0707-tce-27-03-e2850016.pdf.

21. Liang Y, Wang H, Niu M, Zhu X, Cai J, Wang X. Longitudinal analysis of the relationships between social support and health-related quality of life in hematopoietic stem cell transplant recipients. Cancer nurs. [Internet] 2019 [cited 2020 jun 03];42 (3): 251-257. doi: 10.1097/ NCC. 0000000000000616 .

22. Amonoo HL, Brown LA, Scheu CF, Millstein RA, Pirl WF, Vitagliano HL et al. Positive psychological experiences in allogeneic hematopoietic stem cell transplantation. Psycho-oncol. [Internet] 2019 [cited 2019 nov 14];28(8):1633-39. doi: 10.1002/pon.5128

23. Marques ACB, Szczepanik AP, Machado CAM, Santos PND, Guimarães PRB, Kalinke LP. Hematopoietic stem cell transplantation and quality of life during the first year of treatment. Rev. latinoam. enferm. [Internet] 2018 [cited 2019 dez 10];26: e3065. Available from: https://www. scielo.br/pdf/rlae/v26/0104-1169-rlae-26-e3065.pdf.

24. Dóro CA, Neto JZ, Cunha R, Dóro MP. Music therapy improves the mood of patients undergoing hematopoietic stem cells transplantation (controlled randomized study). Support care cancer. [Internet] 2017 [ cited 2019 nov 14];25:1013-1018. doi: 10.1007/s00520-016-3529-z

25. Castellar JI, Fernandes CA, Tosta CE. Beneficial Effects of Pranic Meditation on the Mental Health and Quality of Life of Breast Cancer Survivors. Integr cancer ther. [Internet] 2014 [cited 2020 Jun 13]; 13 (4):341-350. Available from: https://journals.sagepub.com/doi/ pdf/10.1177/1534735414534730.

26. Gurgel IO, Sá PM de, Reis PED dos, Cherchiglia ML, Reis IF, Mattia AL de, et al. Prevalência de práticas integrativas e complementares em pacientes submetidos À quimioterapia antineoplásica. Cogitare enferm. [Internet] 2019 [cited 2020 Jul 01]; 24. Available from: https:// revistas.ufpr.br/cogitare/article/view/64450/pdf

27. Xing L, Guo X, Bai L, Qian J, Chen J. Are spiritual interventions beneficial to patients with cancer? A meta-analysis of randomized controlled trials following PRISMA. Medicine (Baltimore). [Internet] 2018. [cited 2020 jun 03]; 97:359e119480. doi: 10.1097/MD.0000000000011948.

28. Gifford G, Sim J, Horne A, Ma D. Health status, late effects and long-term survivorship of allogeneic bone marrow transplantation: a retrospective study. Intern. med. j. [Internet] 2014 [ cited 2019 jul 24] 44(2):139-147. doi: 10.1111/imj.12336

29. Brice L, Gilroy N, Dyer G, Kabir M, Greenwood M, Larsen S, et al. Haematopoietic stem cell transplantation survivorship and quality of life: is it a small world after all? Support care cancer [Internet] 2017 [ cited 2019 nov 14]; 25(2):421-427. doi: 10.1007/s00520-016-3418-5

30. Sirilla J, Overcash J. Quality of life (QOL), supportive care, and spirituality in hematopoietic stem cell transplant (HSCT) patient. Support. care cancer [Internet] 2013 [ cited 2020 Jun 10];21(4):1137-1144 doi:10.1007/s00520-012-1637-y

31. Seixas MR, Rodríguez LL, Praena FJM, Vázquez MM, Quijano-Campos JC. Calidad de vida relacionada con la salud en pacientes con trasplante de progenitores hematopoyéticos. Index enferm. [Internet] 2014 [cited 2019 nov 16];23(4):209-213. doi: 10.4321/ S1132-12962014000300004

32. El-Jawahri AR, Traeger LN, Kuzmuk K, Eusebio JR, Vandusen HB, Shin JA, et. al. Quality of life and mood of patients and family caregivers during hospitalization for hematopoietic stem cell transplantation. Cancer [Internet] 2015 [cited 2019 nov 12]; 121(5): 951-959. Available from: https://www.ncbi.nlm.nih.gov/pmc/articles/PMC4352120/pdf/nihms649950.pdf 